\title{
PROMOTION OF PRE-SCHOOLER INTELLECTUAL AND WRITING SKILLS WITH DRAWING ACTIVITIES
}

Antra Randoha

Rīgas Pedagogijas un izglītības vadības akadēmija

\begin{abstract}
During the pre-school years, development of balance among intellect, emotions and will is of a great significance. Features forming in child-communication skills and abilities, self-esteem, and speech - cannot develop without intellectual progress. Child, yet not knowing intellect, is willing to be active, study and research, i.e., to challenge own mind, and that takes place trough activities engaging body, objects and physical activities. Psychomotor maturity is one of the indicators of pre-schooler's development; at this age this phenomenon requires specific attention. It is precondition essential for acquisition of drawing and literacy skills - knowledge irreplaceable when accessing basic education. Drawing facilitates intellectual, emotional, and physical development of child (cognition, feelings, perception, thinking, imagination, will, and emotions).
\end{abstract}

Keywords: drawing, intellectual skills, writing skills.

\section{Introduction}

Development of intellectual skills has become a criterion used to learn child's personality. Adults are trying to find out all about possibilities to give children more knowledge and are trying to improve it. However, conditions favourable for development of child are more important than knowledge, since they allow believing that intellectual development of child will take the desired path. Development process itself is very interesting, however not easy.

Currently society attitude towards and understanding of the importance of independent artistic activity (drawing) in facilitation of many-sided development of child's personality is not made topical.

One of the reasons behind the incomplete development of pre-schooler intellectual and literacy skills is a trend related to wide use of modern technologies.

Suitable learning environment as well as available, varied, and rich material base is very important in promoting children initiative for creative activities. Drawing requires qualitative and diverse materials and tools, as they motivate child to work independently, transmitting inner information with the help of lines, colours and shapes. If learning environment ensures materials, moreover if they are varied and multiple, child will be willing to be active, try to finish what has been started and thus develop patience and willpower.

Nowadays and in future computerised writing is more common, therefore acquisition of writing skills requires well-developed muscles and activities of both hands. Also drawing has to employ both hands, as well as to initiate children experience in holding tools, since it eases writing process and reduces hand tension. Improvement of writing skills is of a great significance also in furthering child's concentration skills and attention span. 
Research aims at studying promotion of pre-schooler writing and intellectual skills with drawing activities theoretically and practically.

\section{Materials and Methods}

The paper was written by using theoretical research method - analysis of scientific literature, empirical method - observation of Riga pre-school education establishment children at mixed ages (4-7 years) within pedagogical process. Observation focused on children independent activities when drawing. Observation - purposefully organised qualitative analysis of the facts observed. Analysis of pre-school age children products of the activity is a methodological type of the observation that researches not only activity itself (process), but also result thereof.

Intellectual development of child in early childhood starts already when baby is born, while path of this progress depends upon circumstances, in which child lives, environment created by surrounding people, and place where this all takes place. Communication is very important, since in the result of it child may be directed towards one narrow direction of the intellectual development. J.A.Students suggests preparing mind in a way that it is able to see truth easily and express it in the easiest manner (Students, 1998).

Intellectual abilities - stage of mental development that makes person capable of thinking abstractly; implement main operations of thinking; understand methods or modes of activities that are common for various types of work and training subjects, and to use them to solve new tasks, by making one or another decision, to envisage possible results arising from certain activities or logical occurrence of particular phenomena or events.

$\mathrm{H}$. Gardner in theory of multiple intelligences has distinguished seven criteria for intelligence: linguistic, logically mathematical, musical, bodily kinesthetic, interpersonal spatial and inkling-based (intuitive) abilities (Gardner, 1993, 1999).

Each type of intellect has existed already for a long time and it is characteristic with its own history of evolutionary development. Each type of intellect is responsible for a 'key' or performance of some central operation that is characteristic particularly to it. Results of certain type of intellect may be coded with system of symbols. If one type is fully absent, it does not exclude high level of other types. Each type of intellect may be found with the help of researches or studies. Each of them is characteristic with its own development path that is related to accumulation of particular and specific experience (Bierne, 2009).

Intellectual development of pre-schooler takes place when two opposite poles meet - child's willingness to get emotional impressions by using own activity and external initiates. Basing on upbringing process, pre-school is environment able to ensure many-sided development of a child. Pre-school is the first stage of education, involving may-sided development of personality under the guidance 
of teacher. Child's activity grows along with the age, thus pre-school has to ensure environment suitable for the development of child at pre-school age. One of the most significant growth aspects lies in intellectual development, progress of intellectual abilities. Intellectual activity during the pre-school years engages general cognition ability, capability to understand causal links, terms and notions, activities, as well as to react adequately in various situations.

Refining of intellectual abilities, basing those skills on mental efforts and longstanding mental activity, is rather difficult task related to psychic or mental processes. We inherit intellectual skills biologically, while they are activated by social experience, education, and social, family and cultural environment (Fišers, 2005). Each child develops in his own unique way.

Basing on J.Piaget theory about intellectual development of children, thinking of child fulfils the main role in development of cognitive process. Child interprets world before he learns to speak or walk. He unconsciously forms inner scheme known or unknown. Grounding on this scheme child perceives world, grouping conceptions and images, associations that have been stored in memory (Piažê, 2002).

Intellect is able to change. Thus, as child grows and matures, also intellect develops. Reasons behind the changes and development of intellect are varied. However, mental challenge (situation) and readiness to accept it has major importance. Development of intellect is influenced by factors having effect on activity thereof, and that, in turn, influences motivation of it, namely, social and cultural factors (environment, upbringing, socialisation), personality factors (necessity for cognition, activity, interests, needs), neuro-physiological factors (genetic programme, types of higher nervous activity, peculiarities of nervous processes) (Samusēviča, 2005).

Intellectual development of pre-school age children is closely related to visual arts, i.e., drawing.

Visual arts has great influence on development of will and concentration, therefore child should be able to choose from suitable tasks, accomplish the works started - from creative experience to final result. During the process, child gets satisfaction for the work done and gains invaluable emotional experience (Anspaks, 2004).

Whereas drawing is a kind of visual arts, within the framework of which children depict the most typical features of object in plane with the help of lines, colours, and silhouettes. When drawing also all psychic processes of child feelings, perception, memory, imagination, attention and will - are facilitated (Frīdenberga, 2003).

Within the drawing process:

- visual image is created;

- form or shape is learned and studied;

- coordination of apperception (sensory perception) and motor actions takes place (Kalote, 1999). 
Technical drawing skills have sensory-motor nature. Each of them includes movements made by hand as well as perception and control of movements. Movement to be made may be controlled by sight or kinaesthetically. "Visual arts require not only use of hands, but also simultaneous development of hand and eye. Eyesight has to control movement of hand during all stages of image creation. Eye assesses progressing picture and guides formation thereof" (Komarova, 1982).

Drawing not only has to teach child about correct holding of tool, but also helps to learn how to manipulate it plastically and multiply by using various drawing techniques. It means that child has to learn position of hand and tool when performing particular drawing task.

It is of a high importance that till the age of five child has learned grip that ensures freedom of movement for the hand holding a tool. To develop correct grip of a pencil, child has to keep practicing for a long time. Usually clasp discovered by child himself is not correct, and it is very difficult to wean child from it, as this habit-position seems very comfortable. In practice, children are holding drawing tools very differently: in fist, with three fingers too high or too low, in all fingers of the hand etc. (Komarova, 1982).

Thus we may conclude that drawing is significant and indirect way of acquiring writing skills that should be planned purposefully.

Factors linking drawing and writing skills:

- development of small hand muscles - grasp of tools;

- speed, amplitude of hand movement - breadth of swing; versatility of directions -horizontal, vertical, sloping; various strengths of hand pressure; fluency of leading hand movements - certain rhythm, precision;

- visual perception - binocular, coordination of eyes and hand movements, acumen;

- attention span;

- observation and comparing skills;

- rhythm - metrical, commensurate with repetition of particular elements, and free rhythm;

- memory - visual; visual, tactile, emotional, movement, verbal, logical;

- thinking - merging recognised parts into one and vice versa - dismantling, splitting;

- emotions;

- ability to navigate in plane and space;

- patience, will - to see and overcome difficulties faces when reaching the goal;

- independence - ability to start and finish work autonomously.

Factors distinguishing drawing from writing:

- drawing is characteristic with wide macro-area, as compared to microarea necessary for writing - small and limited area between lines; 
- drawing activity is typical with great variety and unlimited rage for activity, as images of various sizes and shapes have to be depicted, while writing forms are definite and set (Hibnere, 1998).

Line, colour and shape or silhouette are the main artistic means of expression in children drawings.

Writing skills facilitate ability to do several things simultaneously. It is related to wide literacy process. Writing from the brain organisation point of view is very complicated process, since includes fine and delicate actions of hand muscles taking place simultaneously with thinking, formulation of thought (Azarēviča, Mickēviča, Miḷča, Plociņa, Zabarovskis, 2011).

Writing is reflection of speech in graphical signs. Acquisition of writing skills is closely related to learning to read. The processes take place at the same time and thus have influence on each other, bearing in mind that literacy skills are acquired not only trough learning. Learning to write is a row of mind activities that are based on complicated psychical processes - phonematic perception of speech, analysis and synthesis of sounds, harmonised activity of vision and movement analysers. Before writing, child has to hear the sounds, remember corresponding letters and write them in correct order (Baumane, 1992).

Preparing hand for drawing and writing is closely related to physical and psychical development of child. Pedagogue should bear in mind physical development of child (e.g., ability to sit and work at table), development of small hand muscles by performing various actions, progress of child's psychical processes and senses, attention span and ability to concentrate, capability to show interest, willingness to finish what has been started, accomplish necessary hand movements (draw straight, curved etc. lines).

Drawing classes help to feel free and easy and are serving as foundation for furthering writing skills. Pre-schoolers are willing to express their emotions and feelings in drawings. Joy for participation in play classes developing drawing and writing skills may be achieved through adequate motivation for doing the tasks, because very often child's unwillingness to finish what has been started may be observed.

When learning to write, gradualness should be observed, and this task should not be rushed. Gradually child is learning to supplement his drawings with lines, weaves or zigzags, ornaments, or letter elements till he will be able to depict the letter, own word, or will start to copy other letters. "We should move from the simplest to the most complicated. If child has developed normally, basic categories and knowledge, e.g., vertical and horizontal directions, slopes to one or another side, round, circular, child has learned in drawing, ornament, playlike unwinding imitation of writing" (Peipina, 2002). Such first writing attempts and drawing help child in practicing small motoricity, develop finger muscles, and he becomes increasingly more skilful in creating corresponding signs. Writing tools that may be used are wax crayons, soft, thick pencils, or felt-tip pens. Adults should ensure that child's hand is not tense when drawing, if so 
pedagogue or parents should keep observing grasp of tool and suggest child to play finger games, thus releasing hand muscles.

Drawing process should engage various activities developing small hand muscles: drawing balls of yarn, ornamental drawings, copying, circumscribing, colouring, drawings of geometrical figures, drawing basing on landmarks, dotting, making letter shapes in sand, snow, air, with strings, ribbons, threads and other materials soaked in colour. All the methods are intended not only for acquiring writing mechanism, prepare hand for intellectually and socially difficult activity - writing, but also to get ready for writing letters, develop estimation by sight and sense of rhythm, as well as to inculcate features like attention, patience, will to finish things started till the end, precision, observation and comparing skills. If child's small muscles are well-developed, he does not have problems with learning writing skills.

Main material used to cover with drawings is paper, while it may be very advantageous to offer also sand, snow, asphalt or soil. Technical means or tools and drawing techniques may be very diverse: pencils (of various hardness and colour), crayons (oil, wax, chalk), felt-tip pens, paints (finger colours, watercolours, gouache, oil colour), drawing ink, coal, plant juice, paraffin; tools utilised may include paintbrushes, feathers, cotton buds, straw, natural materials: chestnuts, acorns, stones, wooden discs, constriction materials (foam rubber, bubble wrap, cork) etc. The greater variety, the more child gets from this activity and hand becomes better prepared for writing. Assortment of techniques and materials largely depends upon skills of the pedagogue, his/her willingness to diversify drawing process, arrange and prepare all necessary from the materials and practical options.

However, it is more advisable to draw with crayons, colour pencils and paints. Pens and felt-tip pens preferred by children should be used more rarely for children at older age, as, when drawing with pencil, child is able to regulate pressure rate thus getting lighter or darker line, whereas felt-tip pens always leave identical marks and drawing with them does not require effort, moreover round shape thereof when grasping and holding causes additional tension in hand palm. Activities with paints and paintbrushes exercises estimation by sight and hand muscles, develops attention and accuracy.

Good exercise that should be used is flicking. Child has to try flick over drawing or image in one direction, observing equal distances between lines. Also stencils may be used, or child's feet or palms may be circumscribed with colourful lines. Children with pencil may copy various ornaments. Copies may be made of images of children favourite cartoon characters, afterwards children may colour and cut them out.

In drawing child does no not need demonstrative sample or model, but what he does need is various exercises and techniques, if child is making his drawings basing on previous experience, observations and emotions. While when learning 
to write, it would be advisable to use example; however, child's individual needs and differences, i.e., individuality, should be respected.

S.Peipina in respect to writing interference on drawing process emphasises unfavourable influence of writing to drawing, causing small and sloping images that are arranged in lines (Peipina, 2002).

Exercises for acquiring writing skills are based on multiple line types and require observing principles of regularity, individual approach and difficulty levels (irregular lines; straight lines: vertical, horizontal and sloping; wavy, rounded, winding lines; circles and ovals; letter elements and letters on line)s. Practicing these exercises facilitates not only writing skills, but also develops small muscles and coordination of eye-hand, as well as furthers ability to navigate in plane and promotes attention and ability to concentrate etc.

There are no children making bad drawings; each child draws differently and in line with own abilities, while skills are improved only when practicing. There are no children who cannot (don't know how to) draw, while there are children not willing to draw anymore, because adults have not supported them and have not understood their initial interest about graphical classes (LadaGrodzicka,1995).

If pre-schooler is drawing on small area, hand muscles get very tense, whereas working on wide area (at least A4) ensures favourable conditions for free and natural drawing process using movement amplitude suitable for age and temperament (Geka, 2006).

Process how writing skills are acquired is very individual for each child. Pedagogue may work with several children simultaneously, whereas each of them learns the skills in own tempo. Pre-schooler's ability to work alone, that may be developed with the help of drawing, is a factor of a great significance in furthering writing and intellectual skills, offering child interesting, motivating drawing tasks.

Drawing activities for facilitation of intellectual and writing skills:

- continuation of uniform movement - winding of lines - for development of small hand muscles; child draws spiral, curved lines on paper, links elements, supplements, develops;

- finishing lines, shapes, arranging thereof in certain rhythm - child continues or arranges elements, forms in certain sequence, rhythm, tracery, or ornament following particular example or at own choice and imagination;

- drawing various types of lines, harmonising with some rhythm, music tempo, poem rhythm etc.;

- harmonising hand and eye movements by drawing lines, arcs, circles and practicing not withdrawing hand from paper;

- coordination - development of coordination of both hands by drawing with both hands in turns, creating ornament 'reflections';

- linking - joining several types of lines in one element; 
- harmonisation - alternate or simultaneous use of both hands when drawing lines;

- drawing certain objects using one or several line types;

- depicting lines existing in nature, nearest neighbourhood on plane;

- drawing objects with one characteristic line, movement;

- merging several line types;

- transformation of lines, 'making alive'.

Criteria used to evaluate development of pre-schooler intellectual and writing skills with drawing: precision with which tools are held, ability to navigate in plane, attention and concentration abilities, independence in activity, willingness to finish what was started, activity of thinking processes.

Evaluation of research progress allowed concluding that mainly drawings with continuous line, movements in various directions are prevailing, facilitating development of attention and concentration. For pre-schoolers this is one of the most difficult line drawing methods, because it is related not only to line drawing, but also to depiction of bigger or smaller loops. Children at pre-school age still are tended to withdraw hand from paper and they have difficulty with drawing continuous line in various directions. Capability of mastering pencil and paintbrush facilitates progress of small and precise movements of palm and fingers and well as improves development of simultaneous use of hand and eye. These skills cannot be learned without ability to regulate swing, press and tempo of movements.

Second most common type of drawings included hatchings, discontinued lines, stripes that are short, long, broken, straight or sloping, as well as broken and dotted lines. Such lines are very suitable for children aged 4-7 for regulating hand movements and various strengths of pressing. Not only small muscles of fingers are developed, but also palm muscles, internal and external speech, moreover logical and creative thinking is activated.

For successful development of intellectual and writing skills in pre-school the following pre-conditions of pedagogical process should be ensured:

- opportunity to develop and train muscles of both hands by direct and indirect simultaneous and successive activity of hands, diverse and multiple actions, as well as working with natural materials;

- children should be offered to play various finger games and read rhymes;

- pedagogue during process should work together with child and encourage, interest pre-schoolers to draw every day or several times a week;

- drawing technique should be diversified by using various materials;

- children should have opportunity to choose from multiple drawing tools (square pencils, paintbrushes of various sizes, cotton buds, straw, penholders, twigs, stamps etc.);

- pedagogues should ensure healthy environment: suitable lighting, fresh air; 
- during drawing process children should maintain correct body posture and process should not be too long or too short;

- tool should be held correctly, because hand should not get tired during drawing, since otherwise motivation is lost;

- children should be able to use all senses to study object, subject to be depicted, to feel form thereof, investigate visually, taste, smell (it is important also to understand whether child is audialist, kinesthetic or visualist);

- it is of a great significance to motivate child and facilitate development of his will, to ensure that started drawing, writing, story is finished;

- child's ability to draw or write independently should be promoted;

- pedagogue should create environment and circumstances furthering longer attention span during drawing process;

- drawing process should be diversified by offering various types of drawing, appliques, writing paper, lined and squared paper, newspapers, wallpapers, blackboards, drawing in sand, snow air etc.;

- children should have access to various examples that may inspire to create their own originals of ornaments or traceries, work on drawings started prior that allows continuing and finishing pictures with dotted signs, letter elements as well as to copy or colour them;

- child's willingness to draw or write should be supported;

- adults should show interest about works accomplished by children;

- they should evaluate and praise children for his accomplishments.

When studying and evaluating intellectual skills, pre-school teacher has opportunity to choose the most suitable methods, ones that further development of intellectual skills of each pre-schooler (see table 1).

In daily life, differing types of intellect usually are acting together. The main task to be fulfilled when teaching children to think is to develop each and every intellect type, thus development of person's intellect will take place successively (Fišers, 2005).

Child is individual researcher studying himself and surrounding world. Thus he creates his own way of thinking, attitude towards things and people, perception peculiarities that rise motivation for activity and develops intellectual skills. 
Characterisation of intellectual skills

\begin{tabular}{|l|l|}
\hline \multicolumn{1}{|c|}{$\begin{array}{c}\text { Intellectual } \\
\text { skills }\end{array}$} & \multicolumn{1}{c|}{ Promoting development of skills with drawing activities } \\
\hline Linguistic skills & $\begin{array}{l}\text { Plays with lines, telling stories, drawing after listening to story, telling } \\
\text { story basing on picture - own drawing. }\end{array}$ \\
\hline $\begin{array}{l}\text { Logically } \\
\text { mathematical } \\
\text { skills }\end{array}$ & $\begin{array}{l}\text { Tasks requiring resourcefulness and logical thinking, games with rules, } \\
\text { constructing, experiments with lines, free drawing of lines, 'hatching', } \\
\text { resulting in seeing forms, letters, objects, subjects etc. }\end{array}$ \\
\hline Musical skills & $\begin{array}{l}\text { Drawing accompanied by music - depicting lines basing on feelings } \\
\text { (type of line, intensity, character), rhythm and making rhythms, } \\
\text { listening to music. }\end{array}$ \\
\hline $\begin{array}{l}\text { Bodily kinesthetic } \\
\text { abilities }\end{array}$ & $\begin{array}{l}\text { Various hand exercises, finger games, handicrafts, activities and } \\
\text { actions with natural materials during walk. }\end{array}$ \\
\hline $\begin{array}{l}\text { Interpersonal } \\
\text { abilities }\end{array}$ & $\begin{array}{l}\text { Activities in pairs or groups - line games on large paper with certain } \\
\text { task, improvisation. Making drawing from certain lines. }\end{array}$ \\
\hline Spatial skills & All types of drawing activities using as many materials as possible. \\
\hline $\begin{array}{l}\text { Inkling-based } \\
\text { (intuitive) } \\
\text { abilities }\end{array}$ & $\begin{array}{l}\text { Development of cognitive interest trough practical activities - } \\
\text { observations, reflection or depiction of what has been observed. }\end{array}$ \\
\hline
\end{tabular}

\section{Conclusions}

Intellect those are intellectual abilities of an individual that ensure ability to solve problems and perform creative activities. Heredity is of a great significance in the development of intellect, however also social factors, especially purposeful intellectual upbringing or education, are important as well. Successful development of intellect is based on positive emotional atmosphere in relationships between adults and children and well as among children.

Child's observations are notable for individualisation; moreover they give general insight into general development of a child as a whole. Child's experience of feeling and sensing is formed when getting in touch and assimilating what has been seen and felt in external reality.

Writing is complicated process of activities, successful progress of which largely depends upon development of small hand motoricity, finger dexterity, coordination of vision and hand movements. This process is pedagogical, social and psychological, and within it the principle of gradualness should be observed. When learning to write, it is necessary to use drawing activities with certain tasks that improve precision of movements, coordination, will, independence, attention span.

Pre-schoolers are learning to write trough practical drawing activities in adequate and suitable environment. In drawing it is important to coordinate hand movements with vision. With its specific opportunities drawing helps to learn any study subject, also writing, more in depth by facilitating development of child's creative abilities and emotional sphere. 
To ensure that child develops his writing skills with drawing activities more effectively, material base and planning of classes in pre-school education establishment is of a major significance. If you cannot offer child high-quality pencils, paints, variety of techniques and materials, child does not experience joy for the drawing process, writing and also for the result achieved.

\section{References}

1. Anspaks, J. (2004) Mākslas pedagogiija 1.daļa. Rīga: RaKa, 298 lpp.

2. Azarēviča, J., Mickēviča, S., Miḷča, K., Plociņa, L., Zabarovskis, S. (2011) Rakstītprasmes pilnveide latviešu valodā dažādos mācību priekšmetos 7.-9. klasē. Jelgavas tipogrāfija, 104 lpp.

3. Baumane, A. (1992) Vingrinājumi un diktāti skaņu jaukšanas novēršanai. Rīga: Zvaigzne.

4. Bierne, J. (2009) Eksistenciālais intelekts. // Skolotājs. Nr.5. 64. lpp.-71. lpp.

5. Fišers, R. (2005) Mācīsim bèrniem domāt, Rīga: Raka, 325 lpp.

6. Frīdenberga, B. (2003) Vizuālā māksla pirmsskolā, Rīga: Raka, 104 lpp.

7. Gardner, H. (1993) Multiple intelligences: the theory and practice. USA: Basic Books, $352 \mathrm{p}$.

8. Gardner, H. (1999) Intelligence reframed: Multiple intelligence for 21 st Century. NY.: Basic Books, 304 p.

9. Geka, S. (2006) Konstruktīvie vingrinājumi matemātikā un rakstītmācīšanā bērniem no 5 gadu vecuma. Rīga: SIA Izglīīibas soḷi, 102 lpp.

10. Hibnere ,V. (1998) Bērna vizuālā darbība, Rīga: Raka, 198 lpp.

11. Kalote, G. (1999) Bērnu zìmētprasmes ìpatnības pirmsskolas vecumāa. Pirmsskolas izglìtība, Nr.1, 43. lpp.

12. Komarova, T. (1982) Kā mācìt bèrnam zìmēt. Rīga: Zvaigzne

13. Lada-Grodzicka, A. (1995) Šesgadnieka ABC Rīga: Zvaigzne ABC, 64 lpp.

14. Peipiña, S. (2002) Drukātie burti un cel̦š uz rakstītprasmi. Pirmsskolas izglìtība, Nr.1, 6.-7.1pp.

15. Piažēe Ž. (2002) Bērna intelektuālā attīstība. Pētergailis, 318 lpp.

16. Samusēviča, A. (2005) Intelekta attīstības pètījumi un iespējas. // Skolotājs, Nr.4

17. Students, J.A. (1998) Vispārīgā paidogōgija I daļa, Rīga: Raka, 330 lpp.

Antra Randoha Rịgas Pedagogijas un izglītības vadības akadēmija Imantas 7.līnija 1, Rīga, LV-1083, Latvija

e-pasts: antrarandoha@inbox.lv 